\title{
Patogenisitas Cendawan Metarhizium anisopliae (Metsch) dalam mengendalikan Kepik Hijau (Nezara viridula L.) pada Stadia Perkembangan yang Berbeda di Laboratorium (Pathogenicity of Fungi Metarhizium anisopliae (Metsch) in controlling Green Stink bug (Nezara viridula L.) at Different Developmental Stages in Laboratory)
}

\author{
Ahmad Alwi Azhari', Muhammad Sayuthi ${ }^{2}$, Hasnah $^{2 *}$, \\ ${ }^{1}$ Program Studi Agroteknologi, Fakultas Pertanian, Universitas Syiah Kuala \\ ${ }^{2}$ Program Studi Proteksi Tanaman, Fakultas Pertanian, Universitas Syiah Kuala
}

\begin{abstract}
Abstrak. Nezara viridula (L.) (Hemiptera: Pentatomidae) adalah serangga hama yang bersifat kosmopolit dan mempunyai banyak tanaman inang (polifagus) antara lain kacang-kacangan dan kubis-kubisan. Serangan serangan hama ini dapat menurunkan kualitas dan kuantitas hasil tanaman. Salah satu metoda pengendalian hama yang ramah lingkungan yaitu penggunaan cendawan entomopatogen Metarhizium anisopliae sebagai agen pengendalian hayati yang dapat menyebabkan penyakit green muscardin fungus pada serangga. Keefektifan cendawan entomopatogen sangat dipengaruhi oleh stadia perkembangan inang dan kerapatan konidia cendawan yang diaplikasikan. Tujuan dari penelitian ini adalah untuk mendapatkan konsentrasi yang efektif dari cendawan $M$. anisopliae dan stadia perkembangan serangga yang paling rentan terhadap cendawan M. anisopliae. Rancangan yang digunakan dalam penelitian adalah Rancangan Acak Lengkap faktorial yang terdiri dari 2 faktor yaitu konsentrasi cendawan M. anisopliae: $\mathrm{K}_{1}(4 \mathrm{~g} / 100 \mathrm{ml}), \mathrm{K}_{2}(6 \mathrm{~g} / 100 \mathrm{ml})$ dan $\mathrm{K}_{3}(8 \mathrm{~g} / 100$ $\mathrm{ml}$ ) serta stadia perkembangan serangga: $\mathrm{N}_{1}$ (Nimfa instar 2), $\mathrm{N}_{2}$ (Nimfa instar 4) dan $\mathrm{N}_{3}$ (Imago). Menghasilkan jumlah kombinasi perlakuan 9 dengan 3 ulangan sehingga terdapat 27 unit percobaan. Hasil penelitian menunjukkan bahwa aplikasi cendawan entomopatogen $M$. anisopliae berpengaruh nyata terhadap masa inkubasi, mortalitas, dan waktu kematian dari $N$. viridula. Masa inkubasi tercepat pada 8g/ $100 \mathrm{ml}$ yaitu 1,33 hari dan terlama pada 4g/ $100 \mathrm{ml}$ yaitu 1,44 hari. Masa inkubasi tercepat pada nimfa instar 2 yaitu 1,00 hari dan terlama pada imago yaitu 2,11 hari. Mortalitas tertinggi yaitu pada $8 \mathrm{~g} / 100 \mathrm{ml}$ sebesar 97,67\% dan terendah pada 4g/ $100 \mathrm{ml}$ sebesar 87,78\% pengamatan 8 HSA. Mortalitas tertinggi terjadi pada nimfa instar 2 sebesar 98,89\% dan terendah pada imago sebesar $86,67 \%$ pengamatan 8 HSA. Waktu kematian tercepat pada perlakuan 8g/ 100 $\mathrm{ml}$ sebesar 4,49 hari dan terendah pada perlakuan $4 \mathrm{~g} / 100 \mathrm{ml}$ sebesar 5,50 hari. Waktu kematian tercepat pada nimfa instar 2 sebesar 4,31 hari dan terendah pada imago sebesar 6,00 hari. Cendawan entomopatogen $M$. anisopliae efektif dalam mengendalikan $N$. viridula pada nimfa instar 2 dengan konsentrasi 8g/ $100 \mathrm{ml}$.
\end{abstract}

Kata Kunci: Patogenisitas cendawan, Metarhizium anisopliae, kepik hijau, Nezara viridula, stadia perkembangan

Abstract. Nezara viridula (L.) (Hemiptera: Pentatomidae) is a cosmopolitan insect pest and has many host plants (polyphagus) such as beans and cabbage. Attack of the pests can reduce the quality and quantity of crops. One of the most environmentally friendly methods of pest control is the use of entomopathogenic fungus Metarhizium anisopliae as a biological control agent can cause green muscard fungus disease in insects. The effectiveness of entomopathogenic fungi is strongly influenced by the stadia of host development and the density of conidial fungi applied. The aim of this study is to obtain an effective concentration of the fungus $M$. anisopliae and the stages of development of the most vulnerable insects against the fungus $M$. anisopliae. The design used in the study was a Factorial Randomized Complete Random consisting of two factors: the concentration of fungus $M$. anisopliae: $\mathrm{K} 1(4 \mathrm{~g} / 100 \mathrm{ml}), \mathrm{K} 2(6 \mathrm{~g} / 100 \mathrm{ml})$ and $\mathrm{K} 3(8 \mathrm{~g} / 100 \mathrm{ml})$ and stages insect development: N1 (instar nymph 2), N2 (instar nymph 4) and N3 (Adult). Produced a combined number of treatments 9 with 3 replications so that there were 27 experimental units. The result showed that the application of entomopathogenic fungi $M$. anisopliae had significant effect on the incubation period, mortality, and death time of $N$. viridula. The fastest incubation period at $8 \mathrm{~g} / 100 \mathrm{ml}$ is 1.33 days and the longest at $4 \mathrm{~g} / 100 \mathrm{ml}$ is 1.44 days. The fastest incubation period in nymph instar 2 is 1.00 days and the longest in adult is 2.11 days. The highest mortality is at $8 \mathrm{~g} / 100 \mathrm{ml}$ of $97,67 \%$ and the lowest at $4 \mathrm{~g} / 100 \mathrm{ml}$ equal to $87,78 \%$ observation 8 HSA. The highest mortality occurred in instar nymph 2 of $98.89 \%$ and the lowest in adult of $86,67 \%$ observation 8 HSA. The fastest death time in the $8 \mathrm{~g} / 100 \mathrm{ml}$ treatment was 4.49 days and the lowest in the $4 \mathrm{~g} / 100 \mathrm{ml}$ treatment was 5.50 days. The fastest death time in instar nymph 2 is 4.31 days and the lowest is adult at 6.00 days. The entomopathogenic fungus $M$. anisopliae is effective in controlling $N$. viridula in instar nymph 2 with a concentration of $8 \mathrm{~g} / 100 \mathrm{ml}$.

Keywords: Pathogenicity of fungi, Metarhizium anisopliae, Green Stink bug, Nezara viridula, stages development 


\section{PENDAHULUAN}

Kepik hijau (Nezara viridula L.) termasuk dalam ordo Hemiptera dan famili Pentatomidae. Kepik hijau tersebar di seluruh daerah tropis maupun daerah sub tropis, mempunyai tipe alat mulut menusuk dan mengisap yang disebut stilet (Kalshoven, 1981). Serangga ini bersifat kosmopolit dan polifagus yang memiliki tanaman inang lebih dari satu famili seperti tanaman pangan, hortikultura dan palawija (Todd, 1989; Mau \& Kessing, 2007). Umumnya kepik hijau menyerang tanaman pada fase generatif, dimana pada saat pembentukan polong akan terganggu proses pembentukan biji sehingga menyebabkan polong menjadi kempis, mengering dan gugur. Selanjutnya serangan yang terjadi pada saat pengisian biji menyebabkan biji keriput dan terdapat bintik-bintik kecokelatan serta menghitam yang pada akhirnya biji menjadi busuk. Serangga ini aktif merusak pada stadia nimfa dan imago, serta berpeluang besar menyebabkan kehilangan hasil mencapai $80 \%$ pada tanaman kedelai (Panizzi \& Correa, 1997; Correa \& Azevedo, 2002).

Salah satu agen hayati yang dapat digunakan untuk mengendalikan serangga hama adalah cendawan entomopatogen Metarhizium anisopliae Metsch. yang dapat menyebabkan penyakit green muscardin fungus pada serangga. Umumnya cendawan ini menginfeksi serangga karena adanya kontak antara konidia cendawan dengan serangga. Konidia $M$. anisopliae berkecambah membentuk hifa pada segmen tubuh serangga yang lunak dan masuk ke dalam jaringan tubuh serangga dengan bantuan enzim kitinase, protease, dan lipase yang mampu mengurai komponen penyusun kutikula serangga. Setelah masuk ke dalam tubuh serangga, hifa memanjang secara lateral dan berkembangbiak dengan mengonsumsi cairan dari tubuh serangga, sehingga serangga tersebut tidak mampu melakukan metabolisme. Pertumbuhan hifa berlanjut sampai serangga tersebut ditumbuhi dengan miselium berwarna putih, kemudian terdapat bercak berwarna hijau dan menghitam. Hal ini yang mengakibatkan serangga mati dalam keadaan tubuh yang mengeras (Tanada \& Kaya, 1993; Aw \& Hue, 2017).

Keefektifan cendawan entomopatogen sangat dipengaruhi oleh stadia perkembangan inang dan kerapatan konidia cendawan yang diaplikasikan. Serangga muda lebih rentan dari pada serangga dewasa, hal ini disebabkan lapisan lilin serangga muda lebih tipis dibandingkan serangga dewasa sehingga menyebabkan konidia cendawan lebih mudah berpenetrasi ke dalam lapisan kutikula serangga (Prayogo, 2010). Kemudian kandungan lilin yang menutupi kutikula serangga memiliki beberapa senyawa kimia yang dapat menghambat perkecambahan konidia cendawan pada tubuh serangga Toledo et al. (2010).

Cendawan $M$. anisopliae berpotensi dalam mengendalikan berbagai jenis serangga hama seperti ordo Lepidoptera, Coleoptera, Isoptera serta Hemiptera (Prayogo, 2006). Hasil penelitian Trizelia et al. (2010) aplikasi suspensi cendawan $M$. anisopliae isolat asal tanah dari pertanaman kubis pada larva Crocidolomia pavonana instar 2 sebanyak $10^{8} \mathrm{konidia} / \mathrm{ml}$ menghasilkan mortalitas $66,63 \%$ pada 7 HSA dengan nilai $\mathrm{LT}_{50}$ yaitu 4,65 hari. Selanjutnya hasil penelitian Susanti et al. (2012) aplikasi M. anisopliae pada imago kepik hijau dengan konsentrasi $45 \mathrm{~g} / \mathrm{L}$ menghasilkan nilai $\mathrm{LT}_{50}$ 189,00 jam dan rata-rata mortalitas adalah 90,00\% pada 12 HSA.

\section{METODE PENELITIAN}

\section{Tempat dan Waktu Penelitian}

Penelitian ini dilaksanakan di Laboratorium Hama Tumbuhan Program Studi Proteksi Tanaman Fakultas Pertanian Universitas Syiah Kuala dan Laboratorium UPTD Balai Proteksi

Patogenisitas Cendawan Metarhizium anisopliae (Metsch) dalam mengendalikan Kepik Hijau (Nezara viridula L.) pada Stadia Perkembangan yang Berbeda di Laboratorium (Ahmad Alwi Azhari, Muhammad Sayuthi, 
Tanaman Perkebunan Dinas Pertanian dan Perkebunan Aceh. Penelitian ini dilakukan dari bulan April sampai Juli 2017.

\section{Alat dan Bahan Penelitian}

Alat yang digunakan dalam penelitian ini adalah Laminar Air Flow Cabinet, petridish, spatula, pinset, gunting, erlenmeyer, jarum ose, pisau, bunsen, autoclave, shaker, timbangan analitik, inkubator, stoples, dandang, kompor, tabung gas, saringan, ember, kamera digital (Sony a 5000), mikroskop binokuler (Swift SM-80), klip (hekter) dan alat tulis. Bahan yang digunakan dalam penelitian ini adalah serangga $N$. viridula, tepung PDA (potato dextrose agar), jagung pecah, isolat cendawan $M$. anisopliae koleksi Laboratorium UPTD Balai Proteksi Tanaman Perkebunan Dinas Pertanian dan Perkebunan Aceh, aquadest, kain kasa, kertas merang, alkohol 70\%, aluminium foil, spirtus, kacang panjang, kertas label, karet gelang dan plastik tahan panas.

\section{Rancangan Penelitian}

Penelitian ini menggunakan rancangan acak lengkap (RAL) faktorial yang terdiri dari 2 faktor yaitu konsentrasi cendawan $M$. anisopliae: $\mathrm{K}_{1}, \mathrm{~K}_{2}$ dan $\mathrm{K}_{3}$ serta stadia perkembangan serangga: $\mathrm{N}_{1}, \mathrm{~N}_{2}$ dan $\mathrm{N}_{3}$. Jumlah kombinasi perlakuan 9 dengan 3 ulangan sehingga terdapat 27 unit percobaan

Tabel 1. Susunan Kombinasi Perlakuan

\begin{tabular}{cc}
\hline Perlakuan & Konsentrasi \\
\hline $\mathrm{K}_{1} \mathrm{~N}_{1}$ & 4 gram starter jagung $M$. anisopliae $/ 100 \mathrm{ml}$ aquades pada nimfa instar 2 \\
$\mathrm{~K}_{1} \mathrm{~N}_{2}$ & 4 gram starter jagung $M$. anisopliae $/ 100 \mathrm{ml}$ aquades pada nimfa instar 4 \\
$\mathrm{~K}_{1} \mathrm{~N}_{3}$ & 4 gram starter jagung $M$. anisopliae $/ 100 \mathrm{ml}$ aquades pada imago \\
$\mathrm{K}_{2} \mathrm{~N}_{1}$ & 6 gram starter jagung $M$. anisopliae $/ 100 \mathrm{ml}$ aquades pada nimfa instar 2 \\
$\mathrm{~K}_{2} \mathrm{~N}_{2}$ & 6 gram starter jagung $M$. anisopliae $/ 100 \mathrm{ml}$ aquades pada nimfa instar 4 \\
$\mathrm{~K}_{2} \mathrm{~N}_{3}$ & 6 gram starter jagung $M$. anisopliae $100 \mathrm{ml}$ aquades pada imago \\
$\mathrm{K}_{3} \mathrm{~N}_{1}$ & 8 gram starter jagung $M$. anisopliae $/ 100 \mathrm{ml}$ aquades pada nimfa instar 2 \\
$\mathrm{~K}_{3} \mathrm{~N}_{2}$ & 8 gram starter jagung $M$. anisopliae $/ 100 \mathrm{ml}$ aquades pada nimfa instar 4 \\
$\mathrm{~K}_{3} \mathrm{~N}_{3}$ & 8 gram starter jagung $M$. anisopliae $/ 100 \mathrm{ml}$ aquades pada imago \\
\hline
\end{tabular}

\section{Prosedur Penelitian}

\section{Pembiakan Serangga $N$. viridula}

N. viridula diperoleh dari kebun percobaan kemudian dibiakkan di Laboratorium Nimfa dan imago yang diperoleh dari lapangan dimasukkan ke dalam stoples berukuran $8 \mathrm{x}$ $16 \mathrm{~cm}$ yang telah diisi kacang panjang sebagai pakan, kemudian stoples tersebut ditutup dengan kain kasa dan setiap dua hari sekali pakan diganti. Setelah imago berkopulasi dan meletakkan telur, imago tersebut dipindahkan ke dalam stoples lain yang telah berisi kacang panjang. Telur yang menetas, diamati perkembangannya hingga menjadi nimfa instar II, nimfa instar IV dan imago yang digunakan sebagai serangga uji.

\section{Peremajaan Cendawan M. anisopliae pada Media PDA}

Tepung PDA diambil sebanyak 3,9 gram dan dimasukkan ke dalam erlenmeyer sebagai wadah tempat campuran, kemudian ditambah $100 \mathrm{ml}$ aquadest dan diaduk hingga homogen. Selanjutnya larutan tersebut dimasukkan ke dalam autoclave dengan suhu $121^{\circ} \mathrm{C}$ untuk proses pemasakan dan sterilisasi selama 30 menit. Setelah itu erlenmeyer dikeluarkan dari autoclave dan didinginkan selama 10 menit di dalam Laminar Air Flow 
Cabinet. Media PDA yang telah masak dituangkan ke dalam petridish steril yang berdiameter $9 \mathrm{~cm}$ sebanyak $10 \mathrm{ml}$. Selanjutnya cendawan $M$. anisopliae diremajakan dan ditumbuhkan pada media PDA steril dengan cara melepas koloni cendawan menggunakan jarum ose setelah itu biakan cendawan diinkubasi pada suhu $\pm 24{ }^{\circ} \mathrm{C}$ selama 7 hari.

\section{Peremajaan Cendawan $M$. ansiopliae pada Media Jagung}

Hasil dari peremajaan cendawan $M$. anisopliae yang berumur 7 hari ditumbuhkan kembali pada media jagung pecah. Jagung pecah ditimbang sebanyak 300 gr dan dicuci hingga bersih lalu direndam selama 12 jam. Selanjutnya jagung pecah dalam plastik tahan panas dimasukkan ke dalam dandang untuk proses pemasakan dan sterilisasi selama 5 jam 30 menit, lalu diangkat dan didinginkan selama 10 jam. Setelah itu media jagung pecah diinokulasi dengan isolat cendawan M. anisopliae di dalam Laminar Air Flow Cabinet dengan memotong PDA yang telah ditumbuhi cendawan $M$. anisopliae menggunakan spatula, kemudian potongan tersebut dimasukkan ke dalam plastik yang berisi jagung pecah lalu dilipat dan tutup mulut plastik, lalu diklip dengan hekter, media jagung pecah diinkubasi selama 7 hari sambil diremas setiap harinya. Selanjutnya biakan jagung pecah dikeringanginkan selama 2 hari agar dapat disimpan dalam jangka waktu yang lama.

\section{Persiapan Konsentrasi dan Aplikasi Cendawan M. anisopliae}

Biakan cendawan $M$. anisopliae dalam media jagung pecah selanjutnya ditimbang sesuai dengan perlakuan yaitu 4, 6 dan 8 gr. Kemudian masing-masing konsentrasi tersebut dicampur dengan aquadest sebanyak $100 \mathrm{ml}$ lalu diaduk menggunakan shaker \pm 30 menit. Aplikasi pada masing-masing perlakuan dilakukan dengan cara mencelupkan serangga uji pada tiap unit perlakuan (masing-masing 10 ekor serangga sesuai dengan perlakuan) dan ditambah 3 unit kontrol yang hanya dicelupkan dengan aquadest. Setelah dicelup, serangga uji dimasukkan ke dalam stoples yang diberi kacang panjang dan ditutup dengan kain kasa. Selanjutnya diamati sesuai dengan peubah.

\section{Peubah yang diamati.}

\section{Masa Inkunasi Cendawan M. anisopliae terhadap $N$. viridula (hari)}

Masa inkubasi merupakan waktu yang dibutuhkan cendawan $M$. anisopliae untuk menimbulkan gejala infeksi pertama pada $N$. viridula. Umumnya ditandai adanya hifa putih yang tumbuh pada bagian tubuh serangga di awal infeksi cendawan serta perubahan lain yang diamati secara visual pada $N$. viridula. Pengamatan masa inkubasi cendawan dilakukan sejak 1 HSA sampai munculnya gejala infeksi awal pada serangga uji.

\section{Mortalitas N. viridula (\%)}

Pengamatan dilakukan dengan menghitung jumlah $N$. viridula yang mati sejak 1 HSA sampai ada salah satu unit perlakuan yang mati $100 \%$. Perhitungan persentase mortalitas N. viridula dengan menggunakan rumus (Abbott, 1925 dalam Prijono, 1999) sebagai berikut:

Keterangan:

$$
\text { Po }=\frac{r}{\mathrm{n}} \times 100 \%
$$

\section{Po : Mortalitas N. viridula \\ $\mathrm{r}$ : Jumlah $N$. viridula yang mati \\ $\mathrm{n}$ : Jumlah keseluruhan $N$. viridula \\ Waktu Kematian (\%)}

Patogenisitas Cendawan Metarhizium anisopliae (Metsch) dalam mengendalikan Kepik Hijau (Nezara viridula L.) pada Stadia Perkembangan yang Berbeda di Laboratorium (Ahmad Alwi Azhari, Muhammad Sayuthi, 
Waktu kematian adalah rentang waktu yang diperlukan oleh cendawan M. anisopliae sampai menimbulkan kematian pada nimfa dan imago. Waktu kematian nimfa dan imago sangat bervariasi. Kecepatan kematian dihitung dengan interval 1 HSA sampai ada unit perlakuan yang mati $100 \%$. Perhitungan dilakukan dengan menggunakan rumus berikut ini.

$$
\text { Waktu kematian }=\frac{\sum(\text { waktu pengamatan } \mathrm{x} \text { jumlah } N \text {. viridula yang mati })}{\text { Jumlah } N \text {. viridula } \text { awal }}
$$

\section{HASIL DAN PEMBAHASAN}

\section{Masa Inkunasi Cendawan M. anisopliae terhadap N. viridula (hari)}

Hasil analisis ragam menunjukkan bahwa secara mandiri stadia perkembangan $N$. viridula berpengaruh sangat nyata terhadap masa inkubasi cendawan $M$. anisopliae. Sedangkan konsentrasi cendawan tidak berpengaruh nyata terhadap masa inkubasi serta tidak terdapat adanya interaksi antara kedua faktor. Rata-rata masa inkubasi cendawan $M$. anisopliae pada nimfa dan imago N.viridula dapat dilihat pada Gambar 1 (a dan b).
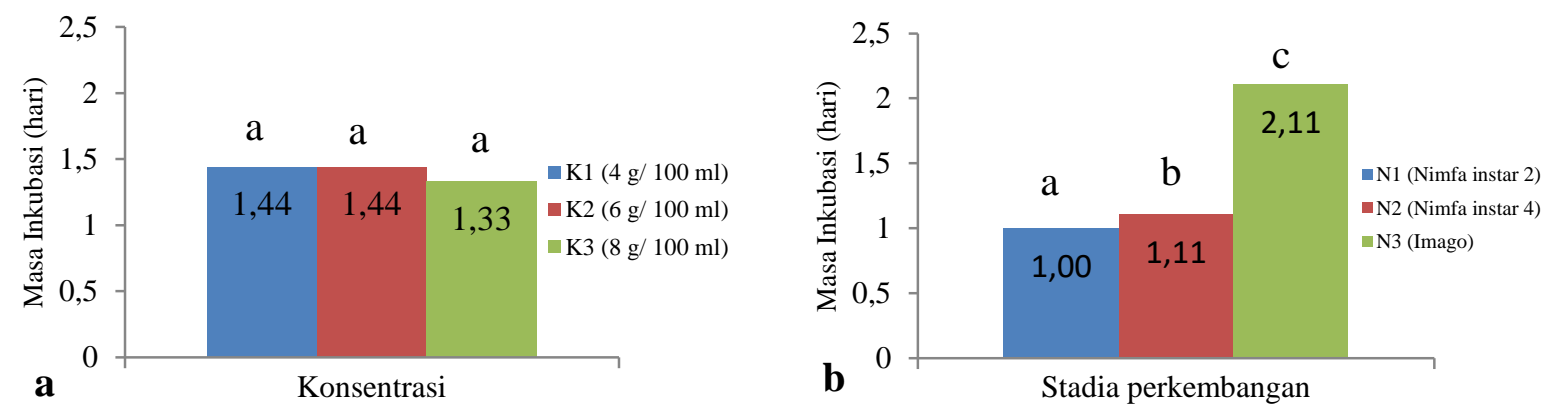

Gambar 1. (a). Masa inkubasi dari cendawan M. anisopliae pada N. viridula dengan konsentrasi yang berbeda. (b). Masa inkubasi dari cendawan M. anisopliae pada stadia perkembangan $N$. viridula yang berbeda (huruf yang sama di atas bar tidak berbeda nyata berdasarkan uji Beda Nyata Terkecil (BNT) taraf 0,05

Berdasarkan Gambar 1a dapat dilihat bahwa masa inkubasi cendawan M. anisopliae tidak berbeda nyata terhadap semua perlakuan. Hal ini diduga karena cendawan memiliki tingkat patogenesitas yang tinggi sehingga bila diaplikasi dengan konsentrasi rendah akan menimbulkan gejala pada tubuh nimfa dan imago $N$. viridula. Hal ini sejalan dengan Sumartini et al. (2001) dalam Prayogo et al. (2005) menyatakan bahwa cendawan entomopatogen $M$. anisopliae merupakan salah satu agen hayati yang potensial untuk mengendalikan serangga hama.

Gambar 1b dapat dilihat bahwa masa inkubasi berbeda nyata antar stadia perkembangan $N$. viridula. Rata-rata masa inkubasi paling cepat terlihat pada nimfa instar 2 yaitu 1,00 hari, diikuti nimfa instar 4 yaitu 1,11 hari dan masa inkubasi paling lama pada imago yaitu 2,11 hari. Masa inkubasi sangat dipengaruhi oleh struktur tubuh serangga, kutikula nimfa instar 2 belum terbentuk sempurna dimana lapisan kitinnya masih tipis dan lunak, sehingga cendawan lebih mudah berpenetrasi ke dalam tubuh serangga. Pada nimfa instar 4 integumen tubuh serangga sudah menebal tetapi belum sempurna, sedangkan pada imago lapisan integumen sudah terbentuk sempurna sehingga cendawan membutuhkan waktu lebih lama untuk berpenetrasi ke dalam tubuh serangga. Gejala awal yang terlihat pada nimfa dan imago yang terinfeksi cendawan yaitu serangga menjadi lemah, kurang aktif bergerak dan daya konsumsi pakan sudah berkurang. Hal ini sesuai dengan pendapat Sedighi et al. (2013) bahwa cendawan membutuhkan waktu lebih dari 24 jam untuk menginfeksi serangga. Selanjutnya proses penetrasi cendawan terjadi ke dalam tubuh serangga dengan bantuan enzim pendegradasi

Patogenisitas Cendawan Metarhizium anisopliae (Metsch) dalam mengendalikan Kepik Hijau (Nezara viridula L.) pada Stadia Perkembangan yang Berbeda di Laboratorium (Ahmad Alwi Azhari, Muhammad Sayuthi, 
kutikula seperti lipase, protease, dan kitinase (Aw \& Hue, 2017). Kaya et al. (2016) menambahkan bahwa senyawa kitin pada stadia muda masih sedikit sehingga lapisan integumen masih tipis, sedangkan pada stadia dewasa sudah menebal.

Ulya et al. (2016) menyatakan bahwa gejala yang ditimbulkan akibat aplikasi cendawan M. anisopliae dengan konsentrasi $10^{10} / \mathrm{ml}$ yaitu adanya miselium berwarna putih pada tubuh Lepidiota stigma setelah 6 HSA. Selanjutnya Han et al. (2014) menambahkan bahwa aplikasi cendawan M. anisopliae dengan konsentrasi $10^{9} / \mathrm{ml}$ pada larva instar 2 Spodoptera exigua menimbulkan gejala adanya miselium berwarna putih pada tubuhnya setelah 3 HSA kemudian berubah menjadi hijau setelah 5 HSA.

\section{Mortalitas N. viridula (\%)}

Hasil analisis ragam menunjukkan bahwa secara mandiri konsentrasi cendawan $M$. anisopliae dan stadia perkembangan $N$. viridula berpengaruh nyata terhadap mortalitas $N$. viridula, namun tidak terdapat adanya interaksi antara kedua faktor tersebut. Rata-rata mortalitas nimfa dan imago $N$. viridula pada berbagai konsentrasi cendawan $M$. anisopliae dan rata-rata mortalitas $N$. viridula pada stadia perkembangan yang berbeda pada pengamatan 2, 4, 6 dan 8 HSA dapat dilihat pada Gambar 2 (a dan b).

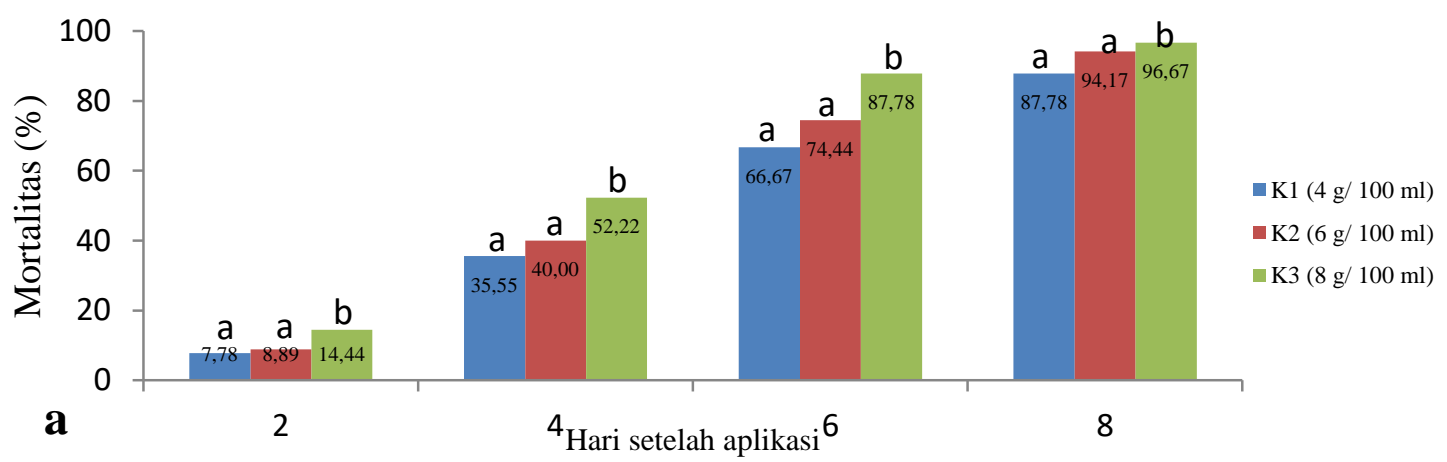

Gambar 2. (a). Mortalitas N. viridula akibat aplikasi cendawan M. anisopliae pada pengamatan 2, 4, 6 dan 8 hari (huruf yang sama di atas bar tidak berbeda nyata berdasarkan uji Beda Nyata Terkecil (BNT) taraf 0,05

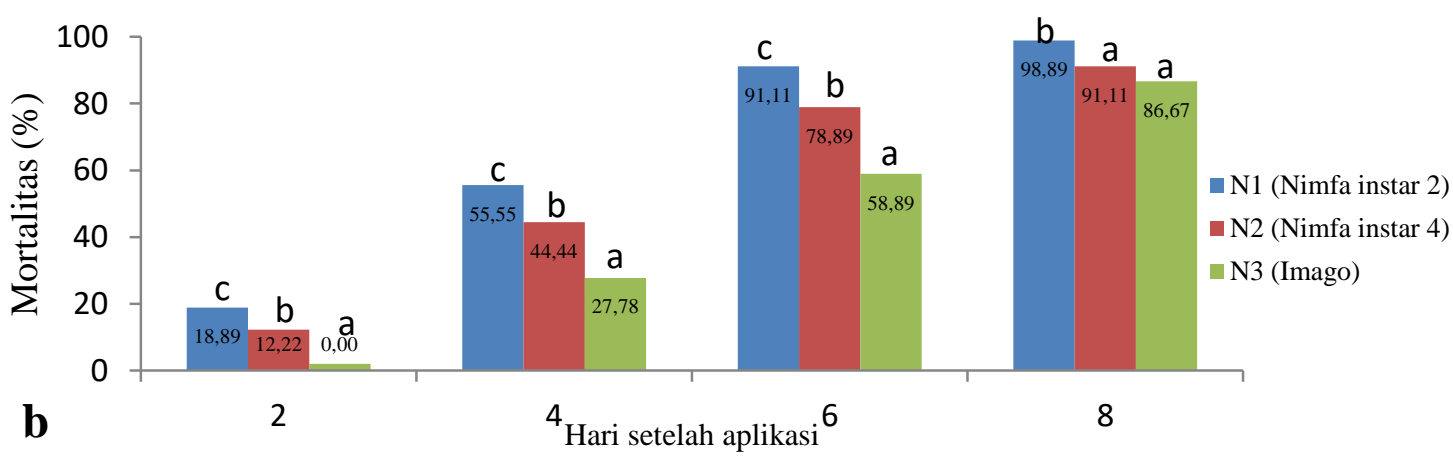

Gambar 2. (b). Rata-rata mortalitas $N$. viridula pada stadia perkembangan yang berbeda pada pengamatan 2,4,6 dan 8 HSA cendawan $M$. anisopliae (huruf yang sama di atas bar tidak berbeda nyata berdasarkan uji Beda Nyata Terkecil (BNT) taraf 0,05

Pada Gambar 2a dapat dilihat bahwa pada 2 sampai 8 HSA ada perbedaan yang nyata antar perlakuan $\mathrm{K}_{3}$ dengan $\mathrm{K}_{1}$ dan $\mathrm{K}_{2}$. Mortalitas tertinggi terdapat pada $\mathrm{K}_{3}$ yaitu 96,67\% diikuti oleh $\mathrm{K}_{2}$ yaitu $94,17 \%$ dan $\mathrm{K}_{1} 87,78 \%$ pada pengamatan 8 HSA. Tinggi dan rendahnya mortalitas disebabkan karena perbedaan konsentrasi yang menyebabkan kerapatan konidia yang menghasilkan enzim dan toksin berbeda. Semakin tinggi konsentrasi cendawan yang diaplikasikan pada $N$. viridula maka semakin tinggi mortalitasnya. Cendawan $M$. anisopliae

Patogenisitas Cendawan Metarhizium anisopliae (Metsch) dalam mengendalikan Kepik Hijau (Nezara viridula L.) pada Stadia Perkembangan yang Berbeda di Laboratorium (Ahmad Alwi Azhari, Muhammad Sayuthi, 
mengelurakan enzim kitinase dan protease yang dapat mendegradasi kutikula pada integumen serangga. Kemudian setelah cendawan masuk ke dalam rongga tubuh serangga, toksin destruxin yang dihasilkan cendawan dapat mengakibatkan terjadinya defisiensi nutrisi dan kerusakan jaringan di dalam tubuh serangga. Hal tersebut dapat menyebabkan kematian pada serangga. Kemudian Schrank \& Vainstein (2010) menyatakan bahwa cendawan M. anisopliae mengeluarkan toksin Destruxin A, E dan B (DA, DE, DB). Selanjutnya Samuels et al. (1988) menambahkan toksin yang dikeluarkan cendawan entomopatogen mampu melemahkan inang dari pertahanan kekebalan tubuh sehingga dapat menyebabkan gangguan fisiologi, kerusakan fisik jaringan atau pengurangan nutrisi, hal ini mempercepat proses kematian inang. Wright \& Cornelius (2012) menyatakan bahwa aplikasi cendawan $M$. anisopliae dengan konsentrasi $10 \% \mathrm{ml}$ menghasilkan mortalitas $7,5 \%$ pada Coptotermes formosanusdan $77,5 \%$ dengan konsentrasi $10^{8} / \mathrm{ml}$ setelah 14 HSA.

Pada Gambar 2b dapat dilihat bahwa pada 2 sampai 6 HSA mortalitas N. viridula berbeda nyata antar stadia perkembangan $\mathrm{N}_{1}, \mathrm{~N}_{2}$ dan $\mathrm{N}_{3}$, namun pada $8 \mathrm{HSA}$ ada perbedaan yang nyata antar stadia perkembangan $\mathrm{N}_{1}$ dengan $\mathrm{N}_{2}$ dan $\mathrm{N}_{3}$. Mortalitas tertinggi pada pengamatan $8 \mathrm{HSA}$ terdapat pada perlakuan $\mathrm{N}_{1}$ yaitu 98,89\% dan terendah yaitu $\mathrm{N}_{3} 86,67 \%$. Perbedaan stadia perkembangan serangga mempengaruhi tinggi rendahnya mortalitas. Nimfa instar 2 memiliki kutikula yang tipis pada integumen, mengakibatkan enzim yang dihasilkan cendawan mudah dalam mendegradasi integumen serangga sehingga proses infeksi semakin cepat. Hal ini menyebabkan nimfa muda lemah dalam mempertahankan kekebalan tubuhnya terhadap serangan cendawan entomopatogen, sehingga peluang terjadinya kerusakan jaringan pada tubuh semakin besar yang menyebabkan kematian pada nimfa, sedangkan imago lapisan kutikula pada integumen sudah terbentuk sempurna, sehingga proses masuknya toksin ke dalam tubuh serangga agak lambat menyebabkan proses kematian membutuhkan waktu lebih lama. Hal ini sesuai dengan pernyataan James (2001) bahwa struktur integumen tubuh nimfa lebih tipis karena lapisan lilin (wax) maupun lipid belum terbentuk secara optimal sehingga konidia yang sudah berkecambah tidak mengalami kesulitan dalam menginfeksi serangga. Selanjutnya Bai et al. (2012) menyatakan bahwa cendawan $M$. anisopliae dapat menghasilkan enzim kitinase, protease dan lipase yang berperan dalam penguraian komponen penyusun kutikula serangga.Ulya et al. (2016) menyatakan bahwa aplikasi cendawan M. anisopliae dengan konsentrasi $10^{10} / \mathrm{ml}$ menghasilkan mortalitas $68,86 \%$ pada instar 2 dan $57,75 \%$ pada instar 3 Lepidiota stigma setelah 10 HSA.

\section{Waktu Kematian $N$. viridula (hari)}

Hasil analisis ragam menunjukkan secara mandiri bahwa konsentrasi cendawan $M$. anisopliae dan stadia perkembangan $N$. viridula berpengaruh sangat nyata terhadap rata-rata waktu kematian, namun tidak terdapat interaksi antara kedua faktor tersebut. Rata-rata waktu kematian nimfa dan imago N. viridula dapat dilihat pada Gambar 3 (a dan b).
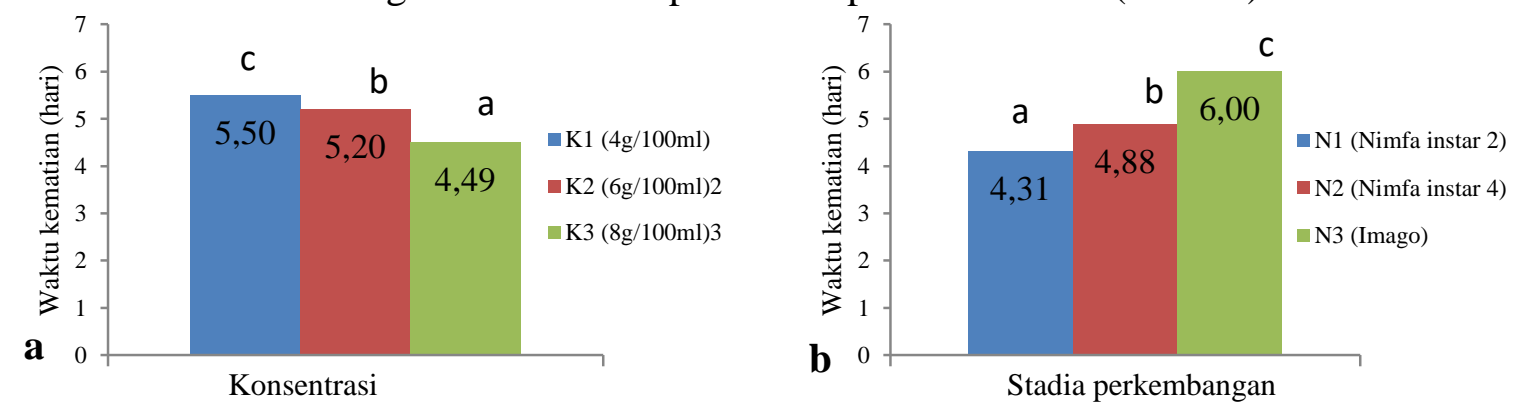

Gambar 3. (a).Waktu kematian N. viridula akibat aplikasi cendawan M. anisopliae pada berbagai konsentrasi. (b). Waktu kematian N. viridula akibat aplikasi cendawan M. anisopliae pada berbagai stadia

Patogenisitas Cendawan Metarhizium anisopliae (Metsch) dalam mengendalikan Kepik Hijau (Nezara viridula L.) pada Stadia Perkembangan yang Berbeda di Laboratorium (Ahmad Alwi Azhari, Muhammad Sayuthi, 
perkembangan (huruf yang sama di atas bar tidak berbeda nyata berdasarkan uji Beda Nyata Terkecil (BNT) taraf 0,05

Gambar 3a menunjukkan bahwa aplikasi cendawan $M$. anisopliae berbeda nyata terhadap waktu kematian dari $N$. viridula. Waktu kematian tercepat pada $\mathrm{K}_{3}$ yaitu pada 4,49 hari kemudian diikuti $\mathrm{K}_{2}$ yaitu pada 5,20 hari dan $\mathrm{K}_{1}$ yaitu pada 5,50 hari. Semakin tinggi konsentrasi cendawan yang diaplikasikan, maka tingkat kerapatan konidia semakin tinggi, menyebabkan jumlah enzim dan toksin yang dihasilkan lebih banyak, sehingga mempercepat waktu kematian $N$. viridula. Sesuai hasil penelitian Han et al. (2014) menyatakan bahwa aplikasi cendawan $M$. anisopliae konsentrasi $10^{5} / \mathrm{ml}$ menghasilkan nilai $\mathrm{LT}_{50}$ 4,7 hari, sedangkan konsentrasi $10^{8} / \mathrm{ml}$ menghasilkan nilai $\mathrm{LT}_{50} 2,1$ hari pada instar 2 larva Spodoptera exigua. Selanjutnya Susanti et al. (2012) menambahkan bahwa aplikasi konsentrasi cendawan M. anisopliae $25 \mathrm{~g} / \mathrm{L}$ menghasilkan nilai $\mathrm{LT}_{50} 229$ jam sedangkan konsentrasi $45 \mathrm{~g} / \mathrm{L}$ menghasilkan nilai $\mathrm{LT}_{50} 189$ jam pada imago N.viridula.

Gambar 3b memperlihatkan bahwa waktu kematian berbeda nyata antar perlakuan stadia perkembangan $N$. viridula akibat aplikasi cendawan $M$. anisopliae. Waktu kematian tercepat terjadi pada $\mathrm{N}_{1}$ yaitu pada 4,31 hari diikuti $\mathrm{N}_{2}$ yaitu pada 4,88 hari dan $\mathrm{N}_{3}$ yaitu pada 6,00 hari. Semakin muda stadia perkembangan serangga, maka semakin singkat waktu yang dibutuhkan cendawan $M$. anisopliae untuk mempenetrasi ke dalam tubuh kepik hijau sehingga mempercepat kematian. Perbedaan stadia perkembangan berkaitan dengan tebal tipisnya integumen tubuh serangga, integumen serangga terdiri dari kitin, protein dan lipid. Bagi serangga muda ketiga senyawa tersebut masih belum terbentuk sempurna sehingga lapisan tubuhnya masih lunak menyebabkan cendawan lebih mudah mendegradasi lapisan kulit tubuh serangga. Sesuai dengan pernyataan Sedighi et al. (2013) bahwa tingkat ketebalan kutikula pada kulit tubuh serangga sangat berperan dalam proses masuknya cendawan entomopatogen ke dalam tubuh serangga. Begitu juga stadia perkembangan serangga sangat berpengaruh terhadap daya infeksi cendawan entomopatogen, sehingga mempengaruhi waktu kematian. Hasil penelitian Sedighi et al. (2013) menyatakan bahwa aplikasi cendawan $M$. anisopliae isolat Iran715 c pada Eurygaster integriceps dengan konsentrasi $10^{8} \mathrm{konidia} / \mathrm{ml}$, maka nilai $\mathrm{LT}_{50}$ adalah 17,52 hari pada imago dan nilai $\mathrm{LT}_{50}$ pada nimfa instar 5 yaitu 3,45 hari.

Berdasarkan hasil penelitian ini dapat dirangkumkan bahwa cendawan entomopatogen $M$. anisopliae efektif dalam mengendalikan serangga hama $N$. viridula. Aplikasi cendawan $M$. anisopliae dengan konsentrasi $8 \mathrm{gr} / 100 \mathrm{ml}$ pada nimfa instar 2 sudah dikatakan efektif untuk mengendalikan hama ini di laboratorium. Mortalitas N. viridula mencapai 87,78\% pada 6 HSA akibat infeksi cendawan $M$. anisopliae dengan konsentrasi $8 \mathrm{gr} / 100 \mathrm{ml}$ pada stadia nimfa instar 2. Tingginya angka mortalitas dapat mempengaruhi masa inkubasi, persentase penghambat makan dan waktu kematian N.viridula.

\section{KESIMPULAN DAN SARAN}

Semakin tinggi konsentrasi cendawan $M$. anisopliae yang diaplikasikan, maka semakin cepat timbulnya gejala penyakit green muscardin fungus pada N. viridula. Aplikasi suspensi cendawan $M$. anisopliae berpengaruh nyata terhadap masa inkubasi, mortalitas dan waktu kematian $N$. viridula. Aplikasi suspensi cendawan $M$. anisopliae berpengaruh terhadap stadia perkembangan $N$. viridula pada nimfa instar 2 menghasilkan masa inkubasi 1,00 hari, mortalitas 98,89\% dan waktu kematian 4,31 hari. Aplikasi cendawan M. anisopliae 8g/100 ml telah efektif dalam mengendalikan $N$. viridula, karena telah menghasilkan mortalitas $87,78 \%$ pada nimfa instar 2 .

Patogenisitas Cendawan Metarhizium anisopliae (Metsch) dalam mengendalikan Kepik Hijau (Nezara viridula L.) pada Stadia Perkembangan yang Berbeda di Laboratorium (Ahmad Alwi Azhari, Muhammad Sayuthi, 


\section{DAFTAR PUSTAKA}

Alejandra, G., G. J. Jose1, A. Raul, U. Maria, \& L. Claudia. 2014. Susceptibility of different life stages of Blattella germanica (Blattodea: Blattellidae) and Periplaneta fuliginosa (Blattodea: Blattidae) to entomopathogenic fungi. J. Curr. Microbiol.App. Sci. 3(12): 614-621.

Aw, K. M. S. \& S. M. Hue. 2017. Mode of infection of Metarhizium spp. fungus and their potential as biological control agents. J. Fungi 3(30): 1-20.

Bai, N. S., O. K. Remadevi, T. O. Sasidharan, M. Balachander, \& P. Dharmarajan. 2012. Cuticle degrading enzyme production by some isolates of the entomopathogenic fungus, Metarhizium anisopliae (Metsch.). J. Bio-Sci. 20: 25-32.

Correa, F. B. S. \& J. D. Azevendo. 2002. Soybean seed damage by different species of stink bug. J. Agriculture and Forest Entomology. 4: 145-150.

Han, J. H., B. R. Jin, J. J. Kim, \& S. Y. Lee. 2014. Virulence of Entomopathogenic Fungi Metarhizium anisopliae and Paecilomyces fumosoroseus for the Microbial Control of Spodoptera exigua. Artikel Mycobiology. 42(4): 385-390.

James, R.R. 2001. Effect of exogeneous nutrients on conidial germination and virulence against the silverlef whitefly for two hyphomycetes. J. Invertebrate Pathology. 77: 99-107.

Kalshoven. L. G. E. 1981. Pest of Crops in Indonesia. Revised and Translated by P.A. Van Der Laan. Pt. Ichtiar Baru-Van Hoeve, Jakarta.

Kaya, M., K. Sofi, I. Sargin, \& M. Mujtaba. 2016. Changes in physicochemical properties of chitin at developmental stages (larvae, pupa and adult) of Vespa crabro (wasp).

J. Carbohydrat Polymers. 145(10): 64-70.

Mau, R. F. L, \& J. L. M. Kessing. 2007. Nezara viridula (Linnaeus). www.extento.hawaii.edu/kbase/crop/type/nezara.html\#References .Diakses tanggal: 25 maret 2017.

Panizzi, A. R. \& B. S. Correa-Ferreira. 1997. Dynamics in the insect fauna adaptation to soybean in the tropics. J. Trends in Entomology. 1: 71- 88.

Permadi, M. A. 2016. Pemanfaatan cendawan entomopatogen Lecanicillium lecaniilecanii, Beauveria bassiana dan Metarhizium anisopliae sebagai mikoinsektisida terhadap kutu loncat jeruk Diaphorina citri kuwayama (Hemiptera: Liviidae). Tesis. Institut Pertanian Bogor, Bogor.

Prayogo, Y., W. Tengkano, \& Marwanto. 2005. Prospek cendawan entomopatogen Metarhizium anisopliae untuk mengendalikan ulat grayak Spodoptera litura pada kedelai. J. Litbang Pertanian. 24(1): 19-24.

Prayogo, Y. 2010. Efikasi cendawan entomopatogen Lecanicillium lecanii (Zare \& Gams) untuk pengendalian hama kepik coklat pada kedelai. Buletin Palawija 20: 47-61.

Patogenisitas Cendawan Metarhizium anisopliae (Metsch) dalam mengendalikan Kepik Hijau (Nezara viridula L.) pada Stadia Perkembangan yang Berbeda di Laboratorium (Ahmad Alwi Azhari, Muhammad Sayuthi, 
Prijono, D. 1999. Pengembangan dan Pemanfaatan Insektisida Alami. Pusat Kajian Pengendalian Hama Terpadu. Institut Pertanian Bogor, Bogor.

Samuels, R. I., A. K. Charnley, \& S. E. Reynolds. 1988. The role of destruxins in the pathogenicity of 3 strains of Metarhizium anisopliae for the tobacco hornworm Manduca sexta. J. Mycopathologia. 104: 51-58.

Schrank. A. \& M. H. Vainstein. 2010. Metarhizium anisopliae enzymes and toxins. J. Toxicon. 56: 1267-1274.

Sedighi, N., H. Abbasipour, H. Askary, A. S.Gorjan, \& J. Karimi. 2013. Pathogenicity of the entomopathogenic fungus Metarhizium anisopliae var. major on different stages of the sunn pest, Eurygaster integriceps. J. Insect Science. 13(150): 1-9.

Susanti, U., D. Salbiah, J. H. Laoh. 2012. Uji beberapa konsentrasi Metarhizium anisopliae (Metsch) sorokin untuk mengendalikan hama kepik hijau (Nezara viridula) pada kacang panjang (Vigna sinensis L.). Artikel Penelitian. Program Studi Agroteknologi. Universitas Riau.

Tanada, Y. \& H. K. Kaya. 1993. Insect Pathology. Academic Press, inc., New York.

Todd, J. W. 1989. Ecology and Behavior of Nezara viridula. Annual Reviews Inc., Georgia.

Toledo, A.V., A. M. M. R. Lenicov, \& C. C. L. Lastra. 2010. Histopathology caused by the entomopathogenic fungi, Beauveria bassiana and Metarhizium anisopliae, in the adult planthopper, Peregrinus maidis, a maize virus vector. J. Insect Science. 10(35): 1-10.

Trizelia., U. Syam, \& Y. Herawaty. 2010. Virulensi isolat Metarhizium sp yang berasal dari beberapa rizosfer tanaman terhadap Crocidolomia pavonana Fabricus (Lepidoptera: Pyralidae). J. Manggaro. 10(2): 51-56.

Ulya, L. N., T. Himawan, G. Mudjiono. 2016. Uji patogenesitas jamur entomopatogen Metarhizium anisopliae (Moniliales: Moniliaceae) terhadap hama uret Lepidiota stigma F. (Coleoptera: Scarabaeidae). J. HPT 4(1): 24-31.

Wright, M. S. \& M. L. Cornelius. 2012. Mortality and repellent effects of microbial pathogens on Coptotermes formosanus (Isoptera: Rhinotermitidae). Article BMC Microbiology. 12(291): 1-7. 